\title{
Gender Socialisation and its Relation to Women's Work and Family Conflict
}

\author{
CHAI YEE NING ELAINE \& NWANESI PETER KARUBI*
}

\author{
Faculty of Social Sciences and Humanity, Universiti Malaysia Sarawak, 94300 Kota Samarahan, Sarawak, \\ Malaysia \\ *Corresponding author: pknwanesi@unimas.my
}

\begin{abstract}
This article examines the impact of gender socialization in Malaysian families, especially on daughters regarding their perception towards work inside and outside the home. Hence, this study utilized in-depth interview as part of the qualitative methods to obtain quality data needed. The study establishes, that patriarchy environment, especially one with the classic model of 'breadwinner father, housewife mother' creates a pressure on women to bear more household responsibility. Thus, the dominant gender ideologies are entangled with 'motherhood mandate' and 'superior feminine virtue' that is associated with the reason women left the labour force. It was equally necessary to point out here that other agents of socialization such as media, peers and education played its part as well and influenced the respondent's conformity to patriarchal values.
\end{abstract}

Keywords: Family conflict, gender, outside the home, socialisation, work inside

Copyright: This is an open access article distributed under the terms of the CC-BY-NC-SA (Creative Commons Attribution Non Commercial Share Alike 4.0 International License) which permits unrestricted use, distribution, and reproduction in any medium, for non-commercial purposes, provided the original work of the author(s) is properly cited.

\section{INTRODUCTION}

The conceptualisation of notion 'work' is still a narrow one which is limited to either paid work in the public spheres or domestic work in the private spheres (Pettinger, Parry, Taylor, \& Glucksmann, 2005). Over the years, the female labour force participation rate ${ }^{1}$ in Malaysia has improved drastically to $54.3 \%$ in 2016, however it is still considered relatively low than the male labour force participation rate which is at $80.2 \%$ (Department of Statistics Malaysia, 2017). For the prime age category which is defined from 25 to 54 years old, the participation of males in labour market exceeded $90 \%$ as compared to females which was more than 55\% (DOSM, 2017).

Gender socialisation is the process whereby an individual learns the appropriate cultural behaviour of femininity or masculinity that is associated with the biological sex of male and female (Lindsey, 2005). Gender leads to sex as social assumptions about what is important to a male's behaviours determines the way of assigning sex (Ryle, 2002).

According to Department of Statistics Malaysia (2017), 70.94\% of employed women works in the service industry and $17.1 \%$ in the manufacturing industry. In terms of occupations, women only hold $20.41 \%$ of managerial positions but they consist of $73.37 \%$ in terms of clerks and support staffs (DOSM, 2017). Besides gender segregation, one of the salient aspect of gender inequality in workplace faced by women is glass ceiling. Swiss and Walker (1993) states that glass ceiling is contributed by 'maternal wall', where a women's commitment to her job is doubted when she becomes pregnant and subsequently, a mother.

Hollows (2008) in her book on domestic cultures, states that there are 2 main perspectives on the issue of conflict between domesticity and public spheres, which are women either have to leave the domestic arena to fare better in public spheres or women have to be stuck in domestic spheres are they are psychologically unsuitable to compete with men in the workplace where power are held by men and rules are defined by patriarchy. The title homemaker is now being used to gradually replace the term housewife as maintenance of home should not be gendered tasks, but for both men and women (Lindsey, 2005).

Working women seek for job satisfaction and personal rewards as much as men but the difference lies in women having to find the right balance between the dual role they play which is employee and mother or wife (Swiss \&

\footnotetext{
${ }^{1}$ Labour force participation rate consists of those between the age of 15 to 64, including those employed and non-employed. Employment status refers to either an employer, an employee, own account workers and unpaid family workers (Department of Statistics Malaysia, 2017).
} 
Walker, 1993). According to Greenhaus \& Parasuraman as cited in Aminah et. al (1999), the intensity of workfamily conflict is determined based on 3 factors, where one of them is importance of each roles and one's personal role definition. A working woman can be a career-oriented employee or family-oriented employee, and the salience of each role will determine the intensity of the conflict. The imbalance of household responsibilities, motherhood mandate, and conforming to traditional gender roles led to women having to juggle career and children (Swiss \& Walker, 1993). In Malaysian society, where patriarchy is still embedded in our culture. Hence the following research questions: to what extent is gender socialisation a determinant factor on why many women sacrifice their career over family responsibilities? To critically evaluate the perspectives of women regarding work outside home and work inside home

\section{Discuss on Issues of Gender Socialisation}

Ryle (2002) discussed three important theories used in understanding gender socialisation. The first one is Social learning theory which is derived from social psychological theory by Bandura and Skinner. Cognitive development theory is another theory which mainly sees socialisation not only as a process done by agents of socialisation but one in which children has an active role. This theory explains that as children acquire their gender identity through a fixed series of developmental stages, carry out gender typed behaviours and the socialisation process themselves. Lastly, the widely accepted to understand gender socialisation is gender schema theory. Gender schema sorts' behaviour or characteristics associated with masculinity or femininity. Gender schema is related to gender polarization or gender dichotomy in which we see, perceive and interpret the interaction and phenomenon around us in gender coloured lens (Coltrane, 2006).

\section{Women, Work and Family}

The reason women are associated with domestic domain is due to them having what Ryle (2002) called 'superior feminine virtue'. Women are assumed to have superior moral values, as they do not face the pressure and struggles from the public domain. Cultural factors, has placed the expectations on women to prioritise their family over career, and this argument is strengthened by the 'motherhood mandate' (Russo, 1976) and 'superior feminine virtue' (Ryle, 2002). The social role theory (Eagly, 1987) has been used to explain work-family conflict as the multiple roles (wife, mother, and worker) builds pressure and causes strain in either or both domains.

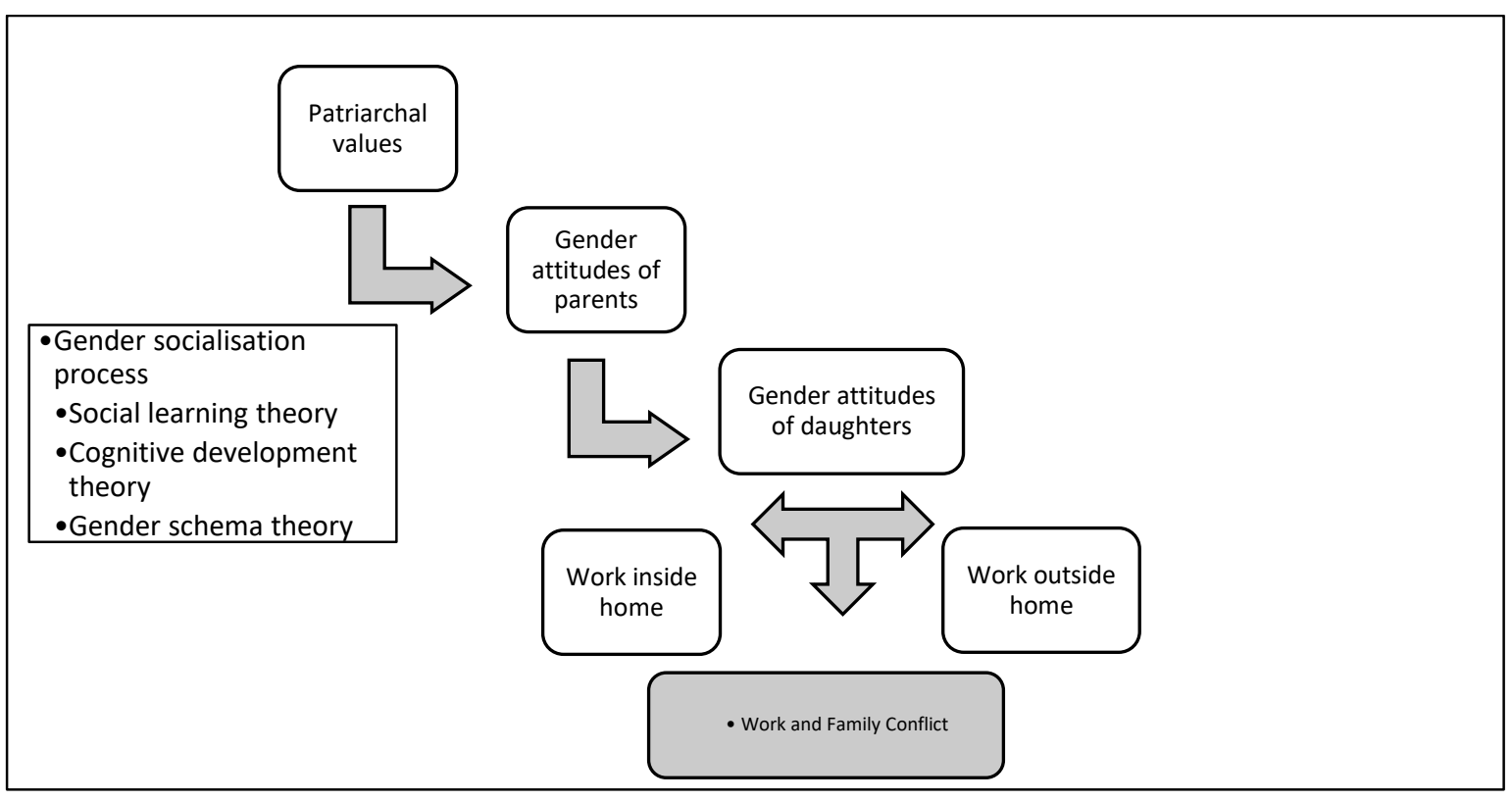

Figure 1. Conceptual framework.

\section{MATERIALS \& METHODS}

Qualitative research is a better option for gender studies as it can capture perspective and personal opinions without confining the options to close-ended questions. As compared to quantitative or mixed method, qualitative method allows the respondents to provide a background story to why they adopt a certain gender view. 
The research population are Malaysian women currently residing in Klang - Valley, West Malaysia. The three major races (Malay, Chinese and Indian) are included in this study. The three ethnic groups were selected as they share similar patriarchal roots in their culture. In this research, the focus is on women as they face stronger workfamily conflict as compared to their male counterpart due to the existing gender ideology.

The respondents are within the age range of 23-40 years old. This is the prime age of working women and the age where they are parents to young children. The respondents are selected using purposive sampling where researcher contacted suitable candidates who fulfilled the criteria among those who volunteered. The sampling size for this research is 10 respondents. The determining factor for this is depending on the quality of data obtained whereby when the data collected reaches a point of saturation, the quota of respondents is reached. The scope of the study is Klang Valley which comprises of Kuala Lumpur, the capital of Malaysia and adjoining cities and towns in the state of Selangor. Klang Valley, is the most populated urban city in Malaysia with a population of over 7.2 million as of 2016. Also this area was selected as the phenomenon of work-family conflict is more evident in an urban setting where dual-income household is more common.

\section{RESULTS \& DISCUSSION}

The findings and discussion section will be will be divided into sub-sections. This is to enable cohesive and logical analysis of the data gathered from the field.

\section{The nature of gender socialisation in the Malaysian family}

Throughout time, patriarchy has not disappeared but changed in form, from private patriarchy to public patriarchy. In the context of Malaysia historically, urban women held a 'reproductive' role while rural women held both 'productive' and 'reproductive' role within their family, but nonetheless both are unpaid work (Jamilah Ariffin, 1992). The nature of gender socialisation that exists in Malaysian family are formed based on this culture as well, as through observation, learning and reinforcement.

Table 1. Family environment of respondents.

\begin{tabular}{llll}
\hline Type of environment & \multicolumn{1}{c}{ Patriarchy } & Controlled environment & Liberal \\
& & & \\
\hline $\begin{array}{l}\text { Words used to } \\
\text { describe }\end{array}$ & $\begin{array}{l}\text { Traditional, } \\
\text { Conservative, } \\
\text { Patriarchal } \\
\text { Respondent A } \\
\text { Respondent B }\end{array}$ & $\begin{array}{l}\text { Boundaries, Well-guided, } \\
\text { Direct, Strict, Fierce }\end{array}$ & $\begin{array}{l}\text { Have freedom, } \\
\text { Not-restricted }\end{array}$ \\
& Respondent C & $\begin{array}{l}\text { Respondent D } \\
\text { Respondent E } \\
\text { Respondent F } \\
\text { Respondent G }\end{array}$ & Respondent H \\
& Respondent I \\
$\begin{array}{l}\text { Rifferential } \\
\text { treatment as } \\
\text { compared to male } \\
\text { siblings }\end{array}$ & $\begin{array}{l}\text { House chores } \\
\text { Curfew }\end{array}$ & $\begin{array}{l}\text { Respondent D: } \\
\text { tendency to praise sons } \\
\text { more }\end{array}$ & Respondent J \\
& & None & \\
\hline
\end{tabular}

Respondent A who grew up in a patriarchy society, states that:

'In this kind of environment, there are 2 types of extreme level you can go, one is you really submit to this kind of belief and become the small little woman behind your husband's back, while the other extreme is you became one who believes in gender equality and that you are as good as men'.

The respondents believe the patriarchy values in Malaysia family are associated with 3 factors, (a) society's norm (b) religion, (c) tradition and culture, and are transmitted through socialisation.

Respondent F: My boss complained to me one day that he feels very stressed, because after his wife quits her job to take care of their kids, she asks him regarding every matter including buying a loaf of bread. You can see how the control went to the men. So, because the wives are spending their husband's money, they try to make him happy that sort of thing.

From the data gathered among the respondents who grew up in a patriarchy household, they state that parental influence is indeed very important, but exposure to mass media, education and environment enables them to 
develop their own perspective, and not constrain themselves to what they see at home. Socialisation process occurs throughout our life. It is a non-ending process, as we continuously learn new norms, new values and conventions to adapt into societal groups. Respondent D talked about how socialisation of patriarchy values can bring about built-in and long-term ideologies based on her observation of her husband:

'My husband doesn't help me because he doesn't know how to, he doesn't want to, and his thinking even to this day, is that he is the breadwinner of the family, he manages the work outside home, so these kind of baby chores are women's job. He has this mindset and he still thinks that way to this day. I don't really agree with my parent in-laws style (of parenting), because they are Hokkien, and you know Hokkien people, they think only a woman should do house chores. They are very traditional. I feel that Hokkien people in general are like that, their parenting style is just like that. When he (husband) grows up, he doesn't have to do anything. My mother in-law is taking care of my son now, so I don't want him to follow her style too much, so I always tell him that 'you have to help out in chores, whenever you can'. She pampers son a lot, that's why to this day, my husband is the type that after he uses a cup, he will just leave it there. He won't even wash and put the cup away after using. He doesn't even know how to cook Maggi. Yeah, he doesn't do much house work, he's very lazy, so I don't bother to ask him to do also.'

The process of socialisation creates a normalizing effect, where we are taught to accept things as 'common-sense', to not question what is taught to us. For instance, gender schema theory by Sandra Bem states that children associate what they see into feminine and masculine attributes such as behaviour, mannerism and social etiquettes.

Most respondents mentioned that growing up, they had restrictions and boundaries in terms of freedom and responsibilities. For respondent $\mathrm{C}$, who grew up in a traditional Indian family and in terms of both chores and curfew for respondent $\mathrm{B}$. The respondent states:

For me, curfew was quite strict, my mom will enforce it and my father observes from far because he was a diplomat and often away, but with the boys, the way we grew up, we always thought it's ok, let them be la. It's fine for boys to stay out late. It doesn't feel so obvious, but when I think about it now, it's obvious. With my younger brother now, he goes out late and nobody cares, but when my younger sister does it, they will start nagging. When it comes to house chores, yeah, it was mostly done by girls too, especially me. For my younger sister, my mom does not care that much anymore (as the parents are now older). It's not that obvious for boys, maybe my mom asked them to do it, but I didn't really notice. For me, they make sure I know how to cook or clean but my brother, no, to the extent when they don't cooperate or help around the house, they don't make a fuss out of it, but when it's me? Hahaha yeah, the sentiment is still there. But surprisingly, when it comes to dating and all that, they are not super strict and forbid me to date, but the curfew is still there. They will tell me don't go to the boy's house and meet his parents yet until I get engaged, and for this I try to follow and I practice it as well, you know there are some things that I still follow the traditional way even though I go for liberal, I try to find a balance lah.

Another form of differential treatment experienced are tendency to praise and compare sons over daughters such as in the case of Respondent D who feels that her mother prefers her brother from the constant comparison she does between them. In terms of house chores, all the respondents are trained from young to participate and help around the house, however, this has more to do with responsibility than patriarchal values, except respondent B and $\mathrm{C}$.

For respondent $\mathrm{D}$ whose mother is also a housewife, she states that

'I also have this thinking, like whatever happens, women have to sacrifice, I think it's a bit weird that wife works, and husbands depend on the wife for income. If the wife earns more, it's still women because I think our society still have this thinking la, and so do I (don't really accept househusbands). If anything happens like in-laws can't take care of the child anymore or especially when you have a special needs kid, then yes, the woman has to sacrifice. If special needs children, you really need to spend a lot of time and attention, and I don't think men can do it.'

Gender socialisation is not a one-way process, but a two-way process as children negotiate their daily gendered experiences in building a gender identity of their own. Respondent A cited her mom as her source of inspiration but disagrees with how her mother conforms to the traditional values.

Respondent A: 'Parental influential is very massive I would say, because my siblings and I see my mom as an entrepreneur, she can survive by herself and raise up 5 children by herself, without a husband by her side I mean, so I believe that's what we all look up to. Most of my siblings tend to be like this, more independent and we have the mentality that we are equal to men, in every sense. But at the same time, when it comes to being a wife, my mom still has the mentality where... when I first found out that my 
first child is a daughter, her concern was how will my mother in-law accepts it. So, she still has that kind of mentality. This time around when I gave birth to my son, even before that, she has been asking my sister if I am having a boy. When I delivered my son, she kept on praising him 'such a handsome boy', this and that, but to me, he just looks like a normal ordinary baby. But yes, she still has that kind of mentality, where parents should praise and pamper sons more than daughters. So, on this part, I would not say, it's a good role model.'

The impact of gender socialisation as well as the parents' division of labour has a deep impact on shaping children's gender view. These are also present when the respondents instil gender roles in their children. Most respondents emphasize on mannerism and self-protection, for daughters and toughness for boys.

Respondent E: 'This one (instilling gender roles) is in terms of manners, I do teach my daughter that a girl has to sit with her legs closed and to speak softly. So, when I do the keep the quiet gesture when she is very loud, she will also follow me and do it. For my son now, when he cries, I will carry him and say things like maybe, don't cry, you are a boy. But most importantly, is to teach them to protect themselves. Like, my daughter she is very friendly, she will smile at you, but she won't let strangers hug her.'

Respondent $\mathrm{F}$ who was raised by a single mother does not have a rigid gender schema. She constantly tries to deconstruct the prevalent gender schema in our society, by being egalitarian in doing gender in her parenting method.

Respondent F: 'Even from young, I let her choose her own toys. She can play masak-masak, she can play tools like those plastic tools, I don't limit her to any toys that she wants to play. Sometimes my in-laws or even my mother will say girls don't speak loudly, I will tell her that everyone shouldn't speak loudly. I use that kind of terms instead of boys or girls should, I instilled this from young. The other day at MPH, I saw stickers with labels - stickers for boys and stickers for girls. I was telling my husband do you mean only boys should know about dinosaurs and girls should know about butterflies? My husband thinks I am a bit over dramatic. So, all these must start from young. My mother in law is a bit traditional in this sense, she thinks girls should be mindful of manners. I won't correct my mother in-law directly, but I will correct my daughter in front of my mother in-law so she knows where I am going.'

It is important to note that gender schema theory relates masculinity and femininity into doing gender, but having a strong ideology of masculinity or femininity are independent with one's view on gender equality.

\section{i. Work inside home and work outside home: Why do women quit?}

The respondents believe the reasons why women leave their career for family are (a) romanticism of motherhood and maternal instinct (b) unsupportive employers and work policies, (c) bad reputation of childcare centre (d) financial capacity and (e) unable to juggle demands from multiple roles. According to Respondent G:

'I think women have the tendency to quite their job because of their own desire. They don't want to miss any precious moments of their kids like first words, first time standing up or things like that. There is also bad reputation of child care centres and being a mother, $u$ take a lot of emergency leaves so that will affect your work as well.'

Another respondent maintains

'I think it all boils down to one factor, their boss. I think a supportive boss, is one who understands women. Regardless of male or female boss, I think they will understand that women have family and children, they have to consider your strength if they want to retain you. I have a friend who is a financial advisor, she wanted to resign because her child is facing some difficulties in studies, but her supervisor appreciates her so they offer her part time, where she only need to come in the office at a certain time, and leave earlier at certain time. That is what I would call a supportive boss. A boss who actually considers your strengths, and offer suitable work policies to assist you (Respondents $\mathrm{H})$.'

\section{ii. Work and family conflict}

The main difficulty in balancing work and family is (a) time management and (b) strain management.

I guess the most challenging thing for me is having a full day at work and going back home to more work. It's like the work never ends. My husband and I will take care of my daughter at night to allow my mother to rest. Basically, I do some of the cleaning at home too. Sometimes I will just snap, because I am very tired and my daughter sticks to me more than my husband. Sometimes I feel very bad, I guess it's the guilt, that I couldn't spend enough time with her, play with her because the time is only so short. So, the guilt is there. Then after you snap, you feel like you are not a good parent. You can't really separate those two clearly, especially when you are stressed at work, and you are tired and then you have a lot of things to take care of at home, occasionally I will just break down and my husband will understand (Respondent F). 
Many respondents agreed that time management is a crucial factor, especially for work from home mothers who takes care of the children by themselves.

The factor of time can lead to mom's guilt. Mom's guilt occurs when mothers feel like they do not attend to the needs of their children due to other commitments that they have. Respondent D points out:

'I think there are some phases (kids demand for attention), when he was 4 years old, he has his own ideas, that time we had a crisis in the company so I had to work overtime almost every day and he can't tell time, so when he saw I haven't return home even though its dark outside, I had to explain to him that I had a lot of work. He cannot accept the reason I told him, so I had to lie to him, and said 'oh there's traffic jam', and he will ask me back 'why is there traffic jam every day' and he actually said 'I know you are lying to me'. After that I felt very bad and guilty, and I know I have to reflect on my own actions because kids, they can understand more than you think so I told myself I can't be like that anymore, I try to go home as early as possible nowadays.'

Work and family conflict first gained attention when the separate spheres are formulated to study the assignment of men to public and women to private. Gerson \& Peiss (1985) suggested boundaries to represent permeability between spheres.

When it comes to the top management in a company, it is often dominated by men. The hierarchies at work are due to gender inequality that is partly created and reproduced by organizational practices (Acker, 1990).

Respondent C: 'I think there is discrimination. I think the moment I started my family after my marriage, this is my third child, in the past 6 years, I have been in the early family stage and I noticed my career has slowed down.

I was lucky I had gotten all my performance increment so far, but I have never gotten any promotion. So, between me and the other person my age, my salary is way lower because my position remains the same due to the traditional roles of women, so the glass ceiling is real.'

Table 2. Division of house chores with spouse and external help engage.

\begin{tabular}{llll}
\hline House chore division with husband & Respondents & $\begin{array}{l}\text { Other help received in } \\
\text { doing house chores }\end{array}$ & $\begin{array}{c}\text { Taking care of } \\
\text { children }\end{array}$ \\
\hline Husband does more & A & $\begin{array}{l}\text { Mother in-law, Part } \\
\text { time maid }\end{array}$ & Mother in-law \\
Husband does less & B & - & Day care centre \\
Equal share & C & $\begin{array}{l}\text { Part time maid, daily } \\
\text { catering }\end{array}$ & Day care centre \\
& J & - & Babysitter \\
& E & Part time maid & Day care centre \\
& F & Mother & Mother \\
& G & Part time maid & Day care centre \\
Husband does not help at all & H & - & Day care centre \\
& D & Mother in-law and maid & Mother in-law \\
\hline
\end{tabular}

The participation of women into the labour force also meant the increased involvement of husbands in work inside home, which includes house chores and taking care of children. As the respondents are all living in Klang Valley and are working full time, most engaged the services of day care centres and part time maid. Respondents who do not send their children to day care centre are staying with their mother or in-laws. Only 1 respondent who is a work from home mother takes care of her children by herself. 
The researcher was interested in how their husbands willingly participate as a family man, despite some growing in a patriarchal environment.

Respondent C: 'He grows up with his grandparents, so it's another generation ago, which is definitely husband at work and wife stay at home. He grew up in that environment where the traditional role is heavily emphasized. At least in my parent's generation, it's not so heavily emphasized. For the generation before that, it's like the husband will scold the wife if she neglects home that kind of thing. But good thing was his grandparents are old, so he had to help out. In a way, he is forced to do some housework. Those days they don't have maids and all to call in and clean the house, the grandma has to do, when the grandma is tired and all that, he will take over and hand wash the clothes. So that's the part of training that he receives that is helping me out.'

The respondents attribute the reason husbands do less chores to none to a few reasons; (a) husband is breadwinner of family (b) men's ego (c) longer working hours (d) lack of initiative.

Respondent I, a work-from-home travel consultant was a full-time house wife for 11 years before she found her current job. She believes men do not participate in house chores due to the patriarchy environment they were raised in.

'To be honest, my husband doesn't do any house chores. He is uninvolved. It is only recently when I started working, that he has slowly started to do more at home. He told me that at one point, he felt that I was going into depression, and it is from then onwards, I guess he realised it and he starts to help me out in small things. It (his unwillingness to help) used to frustrate me a lot. For instance, when we go out, and my son needs to go to the toilet, he will ask me to bring him to the toilet. It's not that he doesn't know how to clean my son or he hasn't done it before, he used to do it with my elder daughter and even his niece, but he will just say 'I don't want to do it'. And if you question more, he will just divert the topic. Ya, I think it has to do with man's ego you know. Sometimes, no matter how much we (society) progress, the older pattern (patriarchy) still surrounds us, and our kids will be influenced by this backwardness too. To achieve gender equality at every matter is difficult. Like my husband, he has the idea that this (children, house chores) are all women's job. He knows how to do it, but he still expects a woman to do it.'

It can be deduced that respondent I's husband held a strong view on masculinity, and hence are unwilling to do feminine tasks. However, to what extent patriarchal socialisation shapes his view on masculine ideology or gender attitude requires more research.

From the responses gathered, the respondents believed some women chose to resign their job after becoming a mother, to fully commit themselves to their role at home.

\section{CONCLUSION}

Most women today work for multiple reasons, whether for self-fulfilment, to have financial independence or to become a role model to their children. The cultural factor taken into consideration for the research purpose is the patriarchal culture in Malaysia.

Patriarchy culture is also interlinked with religion as well as tradition. Tradition has been used as a reason to justify the differential treatment between sons and daughters. Strong patriarchal tradition in Malaysian family can be seen through the domestic division of labour.

Some respondents have a rigid gender schema where they are unable to accept men playing the role of househusbands, as well as some of the respondents' husbands who see house chores as feminine tasks.

Socialisation is the process of transmission of gender values, and values determine gender relations. Patriarchy, essentially is the unequal power relation between men and women, but women are not passive in this maledominated system. In a male-dominated society, male will naturally benefit more whether in private or the public sphere in terms of leisure time, wages, privileges and access to power.

\section{REFERENCES}

Acker, J. (1990). Hierarchies, jobs, bodies: A theory of gendered organizations. Gender \& Society, 4(2), 139-158.

Aminah Ahmad, Nor Hashiah M. Hashim, Arbaiyah Mohd Isa, Siti Rabaah Hamzah. (1999). Role conflict and social support of employed women in industry. In Maimunah Ismail \& Aminah Ahmad (Eds.), Women \& work: Challenges in industrialising nation (pp. 57-80). London: Asean Academic Press.

Coltrane, S. (2006). Engendering children. In Handel, G. (Ed.), Childhood socialization (pp. 279-310). London: Aldine Transaction. 
Department of Statisics Malaysia (2017). Statistik pekerjaan dan perburuhan Malaysia, 13(3). Putrajaya: Malaysia.

Eagly, A. H. (1987). Sex differences in social behaviour: A social role interpretation. Hillsdale, NJ: Erl- baum. Gerson, J. M. \& Peiss, K. (1985). Boundaries, negotiation, consciousness: Reconceptualising gender relations. Social Problems, 32(4), 317-331.

Hollows, J. (2008). Domestic cultures. New York, NY: Open University Press.

Jamilah Ariffin. (1992). Women and development in Malaysia. Petaling Jaya: Pelanduk Publications.

Lindsey, L. L. (2005). Gender roles: A sociological perspective. (4th ed). New Jersey: Pearson Education.

Pettinger, L., Parry, J., Taylor, R. \& Glucksmann, M. (2005). A new sociology of work. London: Wiley-Blackwell. Russo, N. F. (1976). The motherhood mandate. Journal of Social Issues, 32(3), 143-153.

Ryle, R. (2002). Questioning gender: A sociological exploration. London: Sage Publications.

Swiss, D. J. \& Walker, J. P. (1993). Women and the work/family dilemma. New York: John Wiley \& Sons, Inc. 